\title{
Field Geology and Structures of Migmatitic Gneisses Around Ibillo-Okene Area, Southwest Nigeria
}

\author{
Ajigo, I.O. ${ }^{*} \quad$ Odeyemi, I.B. Ademeso, O.A. \\ Department of Applied Geology, Federal University of Technology, P.M.B. 704, Akure, Nigeria
}

\begin{abstract}
Ibillo-Okene migmatites are a typical example of the Basement Complex rocks of southwest Nigerian, which is part of the larger West African shield. They lie directly north and constitute the northern closure of the Igarra Schist Belt. They are interbanded with relics of metasedimentary units called older metasediments as well as overlain by younger metasediments. These units are affected by co-genetic or similar episodes of deformation that has both petrogenetic and economic significance as observed in Igarra Belt south of this area. Though this area is interesting in terms of geology and tectonic setting, detailed geological and structural interpretation of features in the area is lacking due to limited accessibility. Land Sat 8 and shuttle radar topographic mission (SRTM), data constitute useful tools for preliminary reconnaissance survey as well as structural interpretation. Based image interpretation, a minimum of three deformation events were identified: The first event (D1) which is essentially a ductile deformation produced foliations and isoclinal folds which are axial planar such that both the eastern and western limbs of the folds are parallel with regional metamorphic foliation trend S1 (NNW-SSE) and dominant lineament trends (ENE-WSW). The second event (D2) is believed to have produced a progressive reactivation of the D1 event with accentuation of the E-W compression leading to folding of the axes of F1 folds. The third event (D3) has two deformational stages: a ductile deformation at the onset at a higher temperature and pressure and a brittle deformation at the later stages with lower temperature and pressure. Geologic fieldwork which was further conducted to validate structures and units identified from image processing revealed that the migmatites are essentially metatexites which to the northwest is dialational, dialational net-structured in the northeast and straumatic in the southeast. The southwest of the area constitute the basinal closure of the Igarra area overlain by relics of the metasedimentary units. This research underscore the relevance of remotely sensed data in geological investigation whose results have important implications in terms of regional tectonics and geological mapping as well as in land-use planning and other areas such as hydrogeology or geotechnics.
\end{abstract}

Keywords: Migmatite, Ibillo, Okene, metasediments, Remote sensing.

DOI: $10.7176 / \mathrm{JEES} / 9-2-08$

\section{INTRODUCTION}

Migmatites are complex, medium- to high-grade metamorphic rocks formed by partial melting which have been recognised across most of geological time, develop in most tectonic settings, and can affect a wide range of protoliths. They are heterogeneous, medium- to high-grade metamorphic rocks with at least one component formed by partial melting (Pawley et al 2015). Remote sensing involved acquisition and use of relevant satellite data such as Land-Sat and other remotely acquired imageries which have been used extensively in the mineral exploration industry predominantly for the delineation of metalliferous deposits (Airo and Loukola-Ruskeeniemi, 2004). It application ranges from mineral exploration (Murphy, 2007), structure mapping and rock characterization (Telford et al., 1990). Recent advances in technology have substantially increased the accuracy and resolution of these techniques so that they can be used to provide useful enhanced information on lithology and geological structures. Ibillo-Okene area falls within the northern part of Igarra Schist Belts which comprise of two localities in Edo and Kogi states respectively, with a little part to the west in Ondo state. It cut across two topographical sheets of Auchi sheet $266 \mathrm{NW}$ and Kabba $246 \mathrm{SW}$ and falls within Lokoja sheet 62 of the Geological survey 1:250,000 map series. The area has a north-south and east-west lengths of $38.2 \mathrm{~km}$ and $27.3 \mathrm{~km}$ respectively and lies within latitude $7^{\circ}$ $25^{\prime} \mathrm{N}$ and $7^{\circ} 45^{\prime} \mathrm{N}$ and longitude $6^{\circ} 00^{\prime} \mathrm{E}$ and $6^{\circ} 15^{\prime} \mathrm{E}$, an area of approximately $1016 \mathrm{~km}^{2}$. The migmatite gneiss complex covers more than $70 \%$ of the study area. The rocks outcrop with varying topographic relief but generally as rugged hills. This complex extends westwards to Ikare, northwards into Kabba and southwards into Igarra area. It is marginally disposed with respect to the metasedimentary trough in the area.

Migmatites have generally been divided into metatexites and diatexites. A metatexite is a migmatite that is heterogeneous at outcrop scale, with coherent, pre-partial melting structures preserved in the palaeosome (Sawyer, 2008a). In metatexites, the neosome is generally segregated into leucosome and melanosome. Essentially, a metatexite is a migmatitic rock that preserves structural integrity, whether this is primary layering in the protolith, earlier structural elements, or syn-anatectic structures, such as layering. It is important to note that the stresses associated with deformation can precede partial melt. Consequently, it is not unusual to develop an early foliation that can then be exploited once the rock starts to melt and would be considered to be pre-anatexis. A diatexite is a migmatite dominated by pervasive neosome (Sawyer, 2008a). Pre-partial melting structures are absent from the neosome and commonly replaced by syn-anatectic flow structures or isotropic neosome. The neosome is variable 
in appearance, as it typically includes leucosome and melanosome in varying proportions. The palaeosome can occur as rafts or schollen, or it may be absent, (Pawley et al, 2015).

\section{REGIONAL GEOLOGIC SETTING}

A large portion of West Africa sub-region, including the whole of Nigeria, carries the imprint of the LateProterozoic Pan-African Orogeny, whose effects are largely a reworking of older, polycyclic crust. This polycyclic crust has been given dates corresponding to the Liberian (2700 $\pm 200 \mathrm{Ma})$, Eburnian (2000 $\pm 200 \mathrm{Ma})$ and Kibaran $(1100 \pm 200 \mathrm{Ma})$ Orogenic events, (Turner, 1983). The Pan-African province of West Africa lies between two cratons of Archaean to Lower Proterozoic age: the West African Craton to the West and the Congo Craton to the South-east (Figure 1a). Eastward, the Pan-African province probably continues across the whole width of Africa to link with the Mozambique Belt of East Africa; northward it extends through the Hogger massif in the Central Sahara to be truncated by the Alpine fold Belt of North Africa.

The Igarra area, which is directly south of the present study area, has been mapped by Odeyemi 1976, 1977 and 1988. In this area, migmatites and biotite and biotite-hornnblende gneisses are interbanded with low-grade metasediments consisting of schists, calc-silicate gneiss, marbles, polymict metaconglomerate and quartzites. Intrusions of syn- to late-tectonic older granite, charnockite and gabbro cut through the schists, gneisses and migmatites. Dykes of unmetamorphosed dolerite, pegmatite, aplite, lamprophyres and syenites are present in all the pre-existing rock groups. The low grade metasediments (Igarra schist belt) are the most dominant rock in this area.

According to Hockey et al (1986), east of the present study area, around Okene area, the geology comprises of steep-dipping granite gneiss and migmatite give rise to knife-edge ridges. Bands of quartzite which occur both in the migmatite-gneiss complex and in the more schistose areas, form hog-back ridges, covered by rubbles of quartzite fragments. In areas underlain by metasediments, comparatively thin bands of quartzites (and even quartzschists), form distinctive linear ridges because of their relatively greater resistance to weathering.

The geology of the place is dominated by the Nigerian Basement Complex rocks comprising of migmatites overlain by the North-south trending bands of metasedimentary schist as well as the metavolcanics (figure 1b). To the east, the migmatitic gneisses widens out very substantially north and southeast of the district. Metasedimentary units of the Igarra Belt dominate the south, extending up to the southwest of the study area. To the northwest, migmatitic gneisses also dominate, from where they extend to part of the western part of the area.

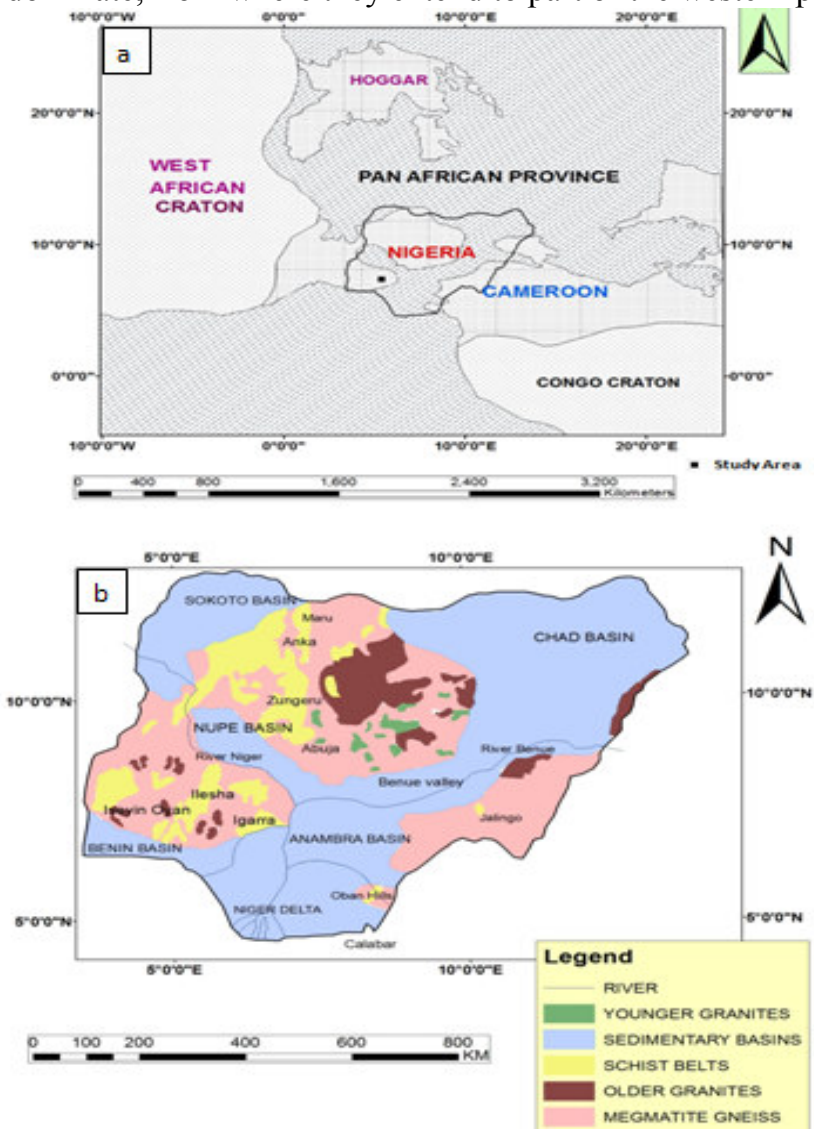

Figure 1: (a) Nigeria and study area within the Pan African Province (b) Generalized Geological Map of Nigeria, (Modified after Ajibade et al, 1988). 


\section{Materials and method}

For this study, Shuttle Radar Topographic Mission (SRTM) digital elevation model (DEM) data and Landsat 8 image (Path/Row-190/055) covering the study area were used. The data used were projected to WGS 1984 UTM Zone $31 \mathrm{~N}$. Several pre-processing techniques were applied on Landsat 8 data before further image processing procedures. The pre-processing techniques include; conversion to top of the atmosphere (ToA) reflectance, sun angle correction and layer stacking. Furthermore, image processing techniques such as principal component analysis (PCA), and false-colour composition (FCC), were applied to the Landsat 8 data to enable lithological discrimination. For structural interpretation, filtering and edge detection techniques were applied on DEM to delineate structural features in the study area.

Reconnaissance survey which is a preliminary field investigation was first carried out followed by a more detailed systematic geological mapping on scale of 1:50,000. This exercise involves the use of topographic map as a guide to locate the outcrops present in the study area. The topographic map was divided into grids to aid mapping and accessibility to different locations. Observations made on each outcrop include megascopic identification of minerals present in the rock outcrops, mineral composition, texture, degree and pattern of weathering, color of fresh rock surface, and measurement of strike and dip values. Equipment used includes compass clinometer, field note book, topographic or base map, ruler, protector, pencils (including colored pencils and markers), hand lens, digital camera, geologic hammer, chisel, sample bags, measurement tape etc.

\section{Results and Discussion}

To understand the tectonic evolution of a region is a complex task particularly when that region is densely vegetated and outcrops are highly weathered. Hence satellite images enables the identification and interpretation of structures difficult to identify in the field particularly in regions where weathering, erosion and deposition has occurred and the deposition of transported erosional debris can mask features relating to the rocks it buries (Drury, 2001). What has been done is to establish a structural framework that will later guide geometrical analysis, during detailed geologic fieldwork.

Structural trends of the study area are captured well by the remotely sensed data. Directional filters (figure 3 ), helps to accentuate fractures and joints (lineaments) while false colour composite and the Normalized Difference Vegetation Index (NDVI) of the LandSat imagery highlighted the regional structures as well as outlines of some of the lithological units (figure 2). Flow direction and hill shade images of the Shuttle Radar Thematic Mapper (SRTM) highlighted both lineament and regional structural trend. Outlines of the major rock units as well as the drainage pattern were fairly accurately delineated. Furthermore, extracted lineament map superimposed on that of drainage showed a structurally controlled pattern of drainage with channels taking their sources from the peak of the hills. 

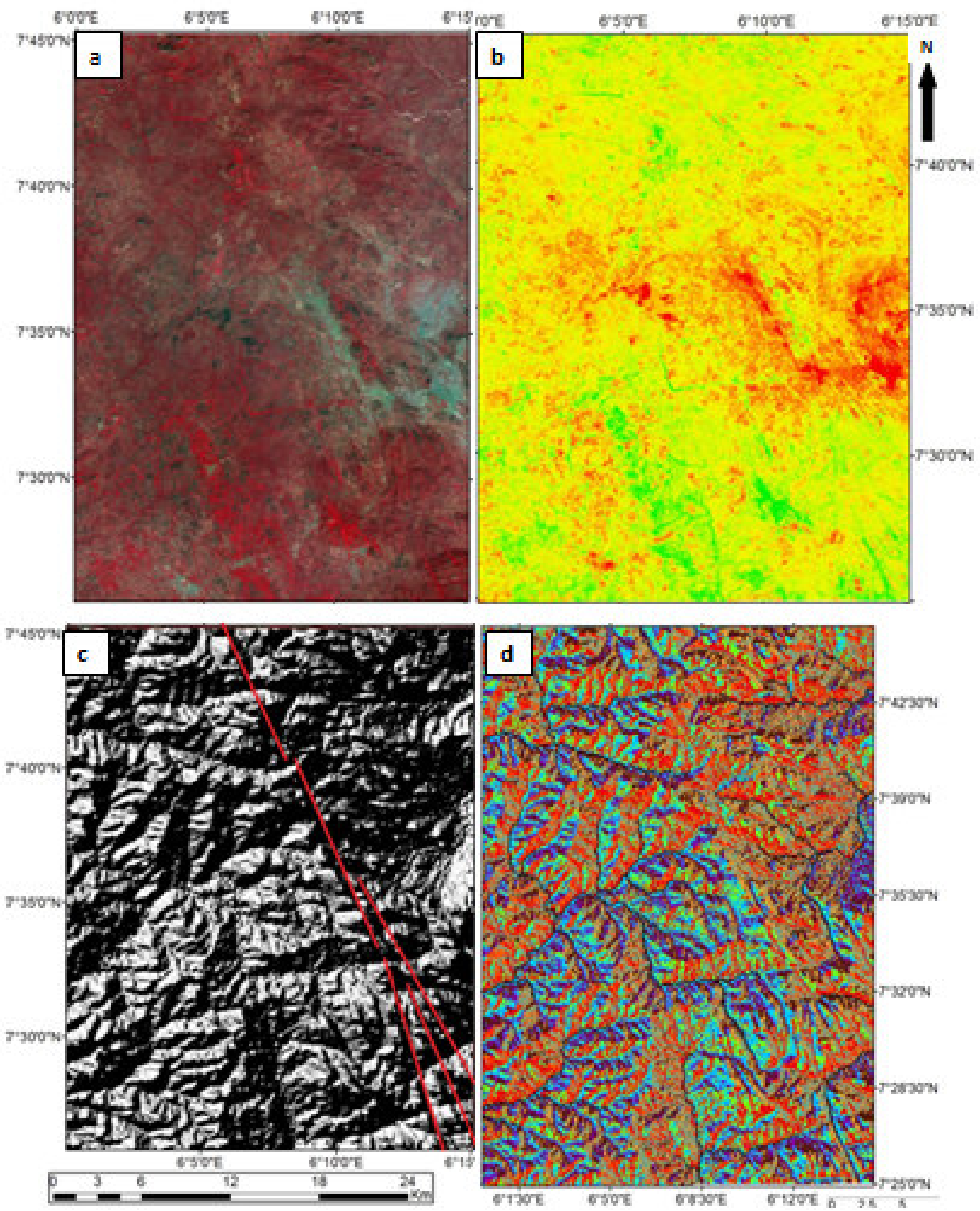

Figure 2: (a) LandSat image of the study area displayed as false colour composite of Red, Blue and Green; (b) Normalized difference vegetation index (NDVI) of the study area, (Green mean high and Red mean low vegetation); (c) Hill shade image data that highlight drainage and fractures: (d) Drainage and flow direction 


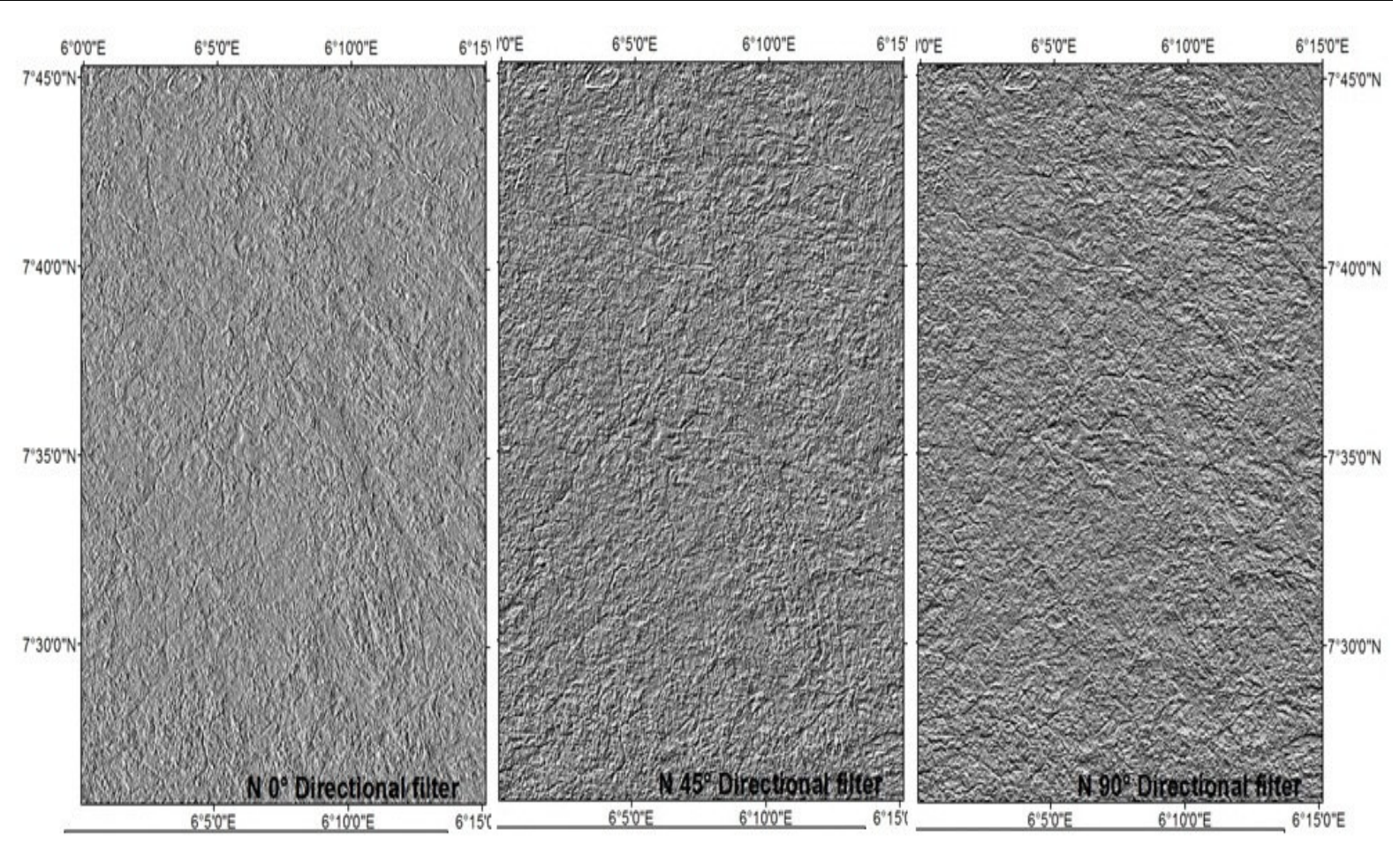

Figure 3: Directional filters to highlight fractures in different directions.

A total of 77 lineaments were extracted through automated method (Table 1.). The extracted lineaments represent valleys, ridges and slope-breaks. The general trend of the lineaments in study area can be described as NW-SE and NE-SW (Figure 5) which is consistent with previous reports by Turner (1983) and Odeyemi (1988). Lengths of lineaments also follow this dominant trend. $\mathrm{N} 45^{\circ}-\mathrm{N} 60^{\circ} \mathrm{E}$ have the highest frequency of lineament which is followed by $\mathrm{N} 65^{\circ}-\mathrm{N} 75^{\circ} \mathrm{E}$ and then $\mathrm{N} 140^{\circ} \mathrm{E}-\mathrm{N} 150^{\circ} \mathrm{E}$. Based on this frequency the trend of the lineaments in the area can be described as NNW-SSE, ENE-WSW and E-W. Most of the lineaments trending in the NW-SE main direction cuts across almost all rock types in the study area particularly quartz schist which occurs as elongate ridges oriented in the northwest-southeast directions, while small proportions of the lineament occurring in the migmatite to the extreme west of the area have NE-WS trend. Within the central part of the study area, the quartz schist is folded to form a tight antiformal structure. Some of the lineaments observed to be associated with quartzite during fieldwork are induced by lithological banding associated with the inter-layering of metasedimentary rocks and while others occur as joints within the quartzite. Other lineament trend associated with the migmatitic rocks occur mainly as fracture mostly trending in the E-W direction.

Based on the computed lineament density areas underlain by migmatite are those with the highest density of lineament followed by areas underlain by metasedimentary rocks. Density of lineaments is generally low in areas underlain by biotite schist and granite gneiss. These areas of relatively high lineament density is shown by the 3Dwire mesh to correspond to the west and south east of the study area, illustrating a peak corresponding to the migmatite/gneiss terrains while depressions correspond to areas underlain by the metasedimentary units. The high lineament density in the migmatite is probably due to their high metamorphic grades, which result in a correspondingly higher resistance to weathering as against the metasediments. 
Table 1: Extracted Lineament data for remote sensing

\begin{tabular}{|c|c|c|}
\hline $\mathrm{S} / \mathbf{N}$ & $\begin{array}{l}\text { AZIMUTH } \\
\left({ }^{\circ}\right)\end{array}$ & $\begin{array}{l}\text { LENGTH } \\
(\mathrm{km})\end{array}$ \\
\hline 1 & 184.53 & 1.13578 \\
\hline 2 & 110.73 & 1.60002 \\
\hline 3 & 152.54 & 3.65577 \\
\hline 4 & 149.01 & 1.85682 \\
\hline 5 & 163.39 & 1.8303 \\
\hline 6 & 333.86 & 1.70344 \\
\hline 7 & 56.91 & 1.87651 \\
\hline 8 & 61.21 & 1.67824 \\
\hline 9 & 147.65 & 1.16492 \\
\hline 10 & 286.44 & 1.0432 \\
\hline 11 & 0 & 1.01695 \\
\hline 12 & 110.98 & 2.41048 \\
\hline 13 & 99.45 & 1.79519 \\
\hline 14 & 93.23 & 3.26779 \\
\hline 15 & 239.75 & 2.06071 \\
\hline 16 & 215.21 & 1.62365 \\
\hline 17 & 44.64 & 2.42514 \\
\hline 18 & 314.65 & 2.08242 \\
\hline 19 & 322.68 & 1.58204 \\
\hline 20 & 330.02 & 2.15312 \\
\hline 21 & 275.1 & 3.43874 \\
\hline 22 & 59.37 & 1.88165 \\
\hline 23 & $\mathbf{5 7 . 7 5}$ & 1.72326 \\
\hline 24 & 84.06 & 5.15108 \\
\hline 25 & 356.31 & 2.2678 \\
\hline 26 & 79.66 & 1.51843 \\
\hline
\end{tabular}

\begin{tabular}{|c|c|c|}
\hline $\mathrm{S} / \mathbf{N}$ & $\begin{array}{l}\text { AZIMUTH } \\
\left({ }^{\circ}\right)\end{array}$ & $\begin{array}{l}\text { LENGTH } \\
(\mathrm{km})\end{array}$ \\
\hline 27 & 25.99 & 1.11969 \\
\hline 28 & 347.44 & 1.07773 \\
\hline 29 & 340.52 & 4.03633 \\
\hline 30 & 127.29 & 2.21826 \\
\hline 31 & 158.35 & 1.61208 \\
\hline 32 & 332.91 & 3.23213 \\
\hline 33 & 123.08 & 1.19693 \\
\hline 34 & 148.23 & 2.19487 \\
\hline 35 & 53.94 & 0.9521 \\
\hline 36 & 34.83 & 0.78377 \\
\hline 37 & 135.44 & 1.1412 \\
\hline 38 & 163.31 & 1.26946 \\
\hline 39 & 54.07 & 1.73415 \\
\hline 40 & 55.34 & 1.70712 \\
\hline 41 & 319.26 & 0.99153 \\
\hline 42 & 33.42 & 3.67461 \\
\hline 43 & 46.95 & 1.15444 \\
\hline 44 & 22.45 & 1.61175 \\
\hline 45 & 122.9 & 1.21563 \\
\hline 46 & 61.26 & 1.4389 \\
\hline 47 & 118.21 & 1.00034 \\
\hline 48 & 12.89 & 1.29091 \\
\hline 49 & 341.97 & 1.32809 \\
\hline 50 & 343.89 & 2.62818 \\
\hline 51 & 55.34 & 1.70729 \\
\hline 52 & 340.74 & 2.08109 \\
\hline
\end{tabular}

\begin{tabular}{|c|c|c|}
\hline $\mathbf{S} / \mathbf{N}$ & $\begin{array}{l}\text { AZIMUTH } \\
\left({ }^{\circ}\right)\end{array}$ & $\begin{array}{l}\text { LENGTH } \\
(\mathrm{km})\end{array}$ \\
\hline 53 & 60.8 & 1.60727 \\
\hline 54 & 23.27 & 1.31737 \\
\hline 55 & 144.12 & 1.96838 \\
\hline 56 & 71.6 & 1.64346 \\
\hline 57 & 321.6 & 1.35878 \\
\hline 58 & 256.01 & 1.30321 \\
\hline 59 & 93.4 & 1.95014 \\
\hline 60 & 120.58 & 1.67026 \\
\hline 61 & 81.38 & 1.28662 \\
\hline 62 & 92.86 & 1.1579 \\
\hline 63 & 97.63 & 1.88633 \\
\hline 64 & 147.17 & 4.97744 \\
\hline 65 & 154.23 & 3.17129 \\
\hline 66 & 111.89 & 2.32645 \\
\hline 67 & 298.98 & 1.43215 \\
\hline 68 & 260.39 & 1.27064 \\
\hline 69 & 160.68 & 1.57272 \\
\hline 70 & 273.23 & 3.26779 \\
\hline 71 & 280.73 & 1.86364 \\
\hline 72 & 125.26 & 1.36902 \\
\hline 73 & 70.27 & 3.12398 \\
\hline 74 & 316.43 & 1.87955 \\
\hline 75 & 230.25 & 2.67997 \\
\hline 76 & 104.04 & 1.43046 \\
\hline 77 & 79.51 & 1.58777 \\
\hline 78 & TOTAL & 147.444 \\
\hline
\end{tabular}


Table 2: Measured attitudes of foliation planes from field

\begin{tabular}{|c|c|c|c|c|c|c|c|c|c|c|c|}
\hline $\mathrm{S} / \mathbf{N}$ & $\begin{array}{l}\text { Azimuth } \\
\left({ }^{\circ}\right)\end{array}$ & Dip & $\begin{array}{l}\text { Dip } \\
\text { Direction }\end{array}$ & S/N & $\begin{array}{l}\text { Azimuth } \\
\left({ }^{\circ}\right)\end{array}$ & Dip & $\begin{array}{l}\text { Dip } \\
\text { Direction }\end{array}$ & $\mathrm{S} / \mathrm{N}$ & $\begin{array}{l}\text { Azimuth } \\
\left(^{\circ}\right)\end{array}$ & Dip & $\begin{array}{l}\text { Dip } \\
\text { Direction }\end{array}$ \\
\hline 1 & 350 & 30 & $\mathrm{~W}$ & 35 & 344 & 50 & $\mathrm{~W}$ & 69 & 339 & 55 & $\mathrm{~W}$ \\
\hline 2 & 359 & 41 & W & 36 & 338 & 49 & W & 70 & 300 & 55 & W \\
\hline 3 & 320 & 30 & W & 37 & 340 & 44 & W & 71 & 40 & 60 & W \\
\hline 4 & 340 & 25 & W & 38 & 352 & 32 & W & 72 & 10 & 55 & $\mathrm{E}$ \\
\hline 5 & 330 & 32 & $\mathrm{E}$ & 39 & 342 & 30 & W & 73 & 6 & 70 & $E$ \\
\hline 6 & 40 & 38 & W & 40 & 323 & 60 & W & 74 & 26 & 42 & $\mathrm{E}$ \\
\hline 7 & 310 & 40 & W & 41 & 350 & 49 & W & 75 & 350 & 40 & $\mathrm{E}$ \\
\hline 8 & 300 & 60 & $\bar{E}$ & 42 & 340 & 60 & $\bar{E}$ & 76 & 80 & 50 & $\mathrm{~W}$ \\
\hline 9 & 350 & 56 & $\mathrm{E}$ & 43 & 335 & 70 & W & 77 & 342 & 40 & W \\
\hline 10 & 350 & 50 & W & 44 & 320 & 68 & W & 78 & 354 & 41 & $\mathrm{E}$ \\
\hline 11 & 340 & 40 & W & 45 & 335 & 70 & W & 79 & 354 & 54 & $\mathrm{E}$ \\
\hline 12 & 50 & 40 & $\mathrm{E}$ & 46 & 336 & 65 & W & 80 & 354 & 52 & W \\
\hline 13 & 340 & 20 & $\mathrm{~W}$ & 47 & 340 & 60 & W & 81 & 325 & 55 & $\mathrm{~W}$ \\
\hline 14 & 340 & 36 & $\mathrm{~W}$ & 48 & 330 & 60 & $\mathrm{~W}$ & 82 & 344 & 46 & $\mathrm{~W}$ \\
\hline 15 & 355 & 30 & $\mathrm{~W}$ & 49 & 69 & 45 & $\mathrm{~W}$ & 83 & 320 & 57 & W \\
\hline 16 & 350 & 30 & W & 50 & 345 & 35 & W & 84 & 350 & 44 & W \\
\hline 17 & 20 & 33 & W & 51 & 325 & 60 & W & 85 & 13 & 56 & W \\
\hline 18 & 16 & 25 & W & 52 & 335 & 60 & W & 86 & 350 & 54 & W \\
\hline 19 & 0 & 25 & W & 53 & 290 & 43 & $E$ & 87 & 345 & 40 & W \\
\hline 20 & 344 & 41 & $\mathrm{~W}$ & 54 & 302 & 42 & $\mathrm{E}$ & 88 & 335 & 70 & W \\
\hline 21 & 339 & 41 & W & 55 & 323 & 60 & W & 89 & 330 & 88 & W \\
\hline 22 & 345 & 29 & W & 56 & 340 & 60 & W & 90 & 355 & 45 & W \\
\hline 23 & 20 & 31 & $\mathrm{~W}$ & 57 & 20 & 70 & W & 91 & 05 & 65 & $\mathrm{~W}$ \\
\hline 24 & 49 & 54 & W & 58 & 310 & 70 & $\mathrm{E}$ & 92 & 355 & 87 & W \\
\hline 25 & 49 & 71 & W & 59 & 340 & 40 & $\mathrm{E}$ & 93 & 330 & 60 & W \\
\hline 26 & 40 & 52 & W & 60 & 10 & 55 & W & 94 & 345 & 35 & W \\
\hline 27 & 12 & 40 & W & 61 & 340 & 88 & W & 95 & 325 & 80 & W \\
\hline 28 & 20 & 29 & $\mathrm{E}$ & 62 & 310 & 50 & W & 96 & 348 & 60 & W \\
\hline 29 & 336 & 35 & W & 63 & 315 & 50 & $\mathrm{E}$ & 97 & 350 & 40 & W \\
\hline 30 & 340 & 28 & W & 64 & 328 & 40 & W & 98 & 340 & 75 & W \\
\hline 31 & 21 & 60 & $\mathrm{E}$ & 65 & 30 & 40 & W & 99 & 333 & 70 & W \\
\hline 32 & 12 & 40 & W & 66 & 355 & 87 & W & 100 & 345 & 40 & W \\
\hline 33 & 340 & 24 & W & 67 & 355 & 65 & W & 101 & 334 & 74 & W \\
\hline 34 & 342 & 38 & W & 68 & 340 & 75 & W & & & & \\
\hline
\end{tabular}

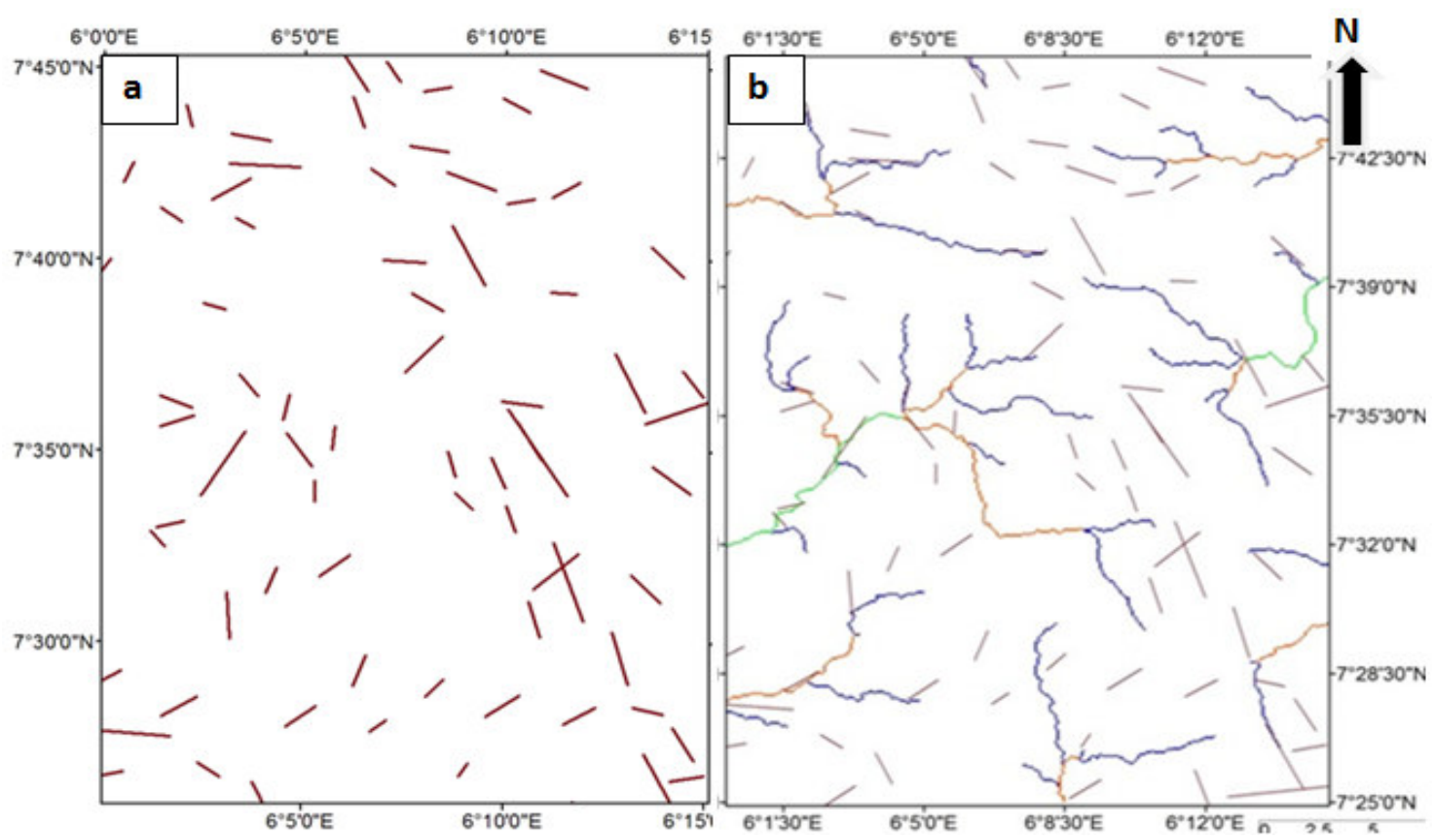

Figure 4: (a) Lineament map derived from remote sensing data of the study area;

(b) Lineament superimposed on drainage map for the study area. 


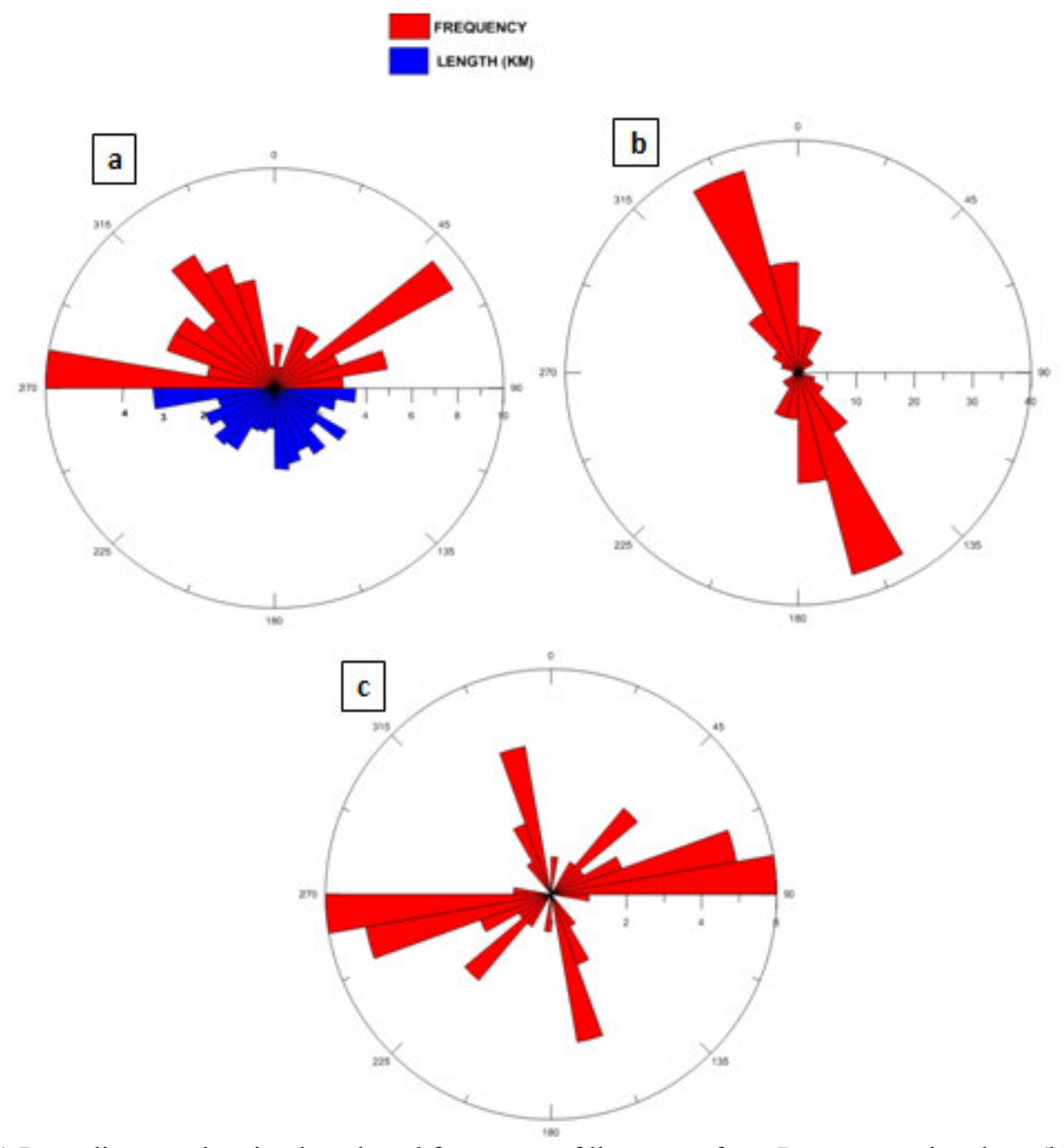

Figure 5: (a) Rose diagram showing length and frequency of lineament from Remote sensing data; (b) Rose diagram showing measured attitudes of foliation planes from field; (c) Rose diagram showing measured attitudes of joints in the field.

Field investigations revealed that there are six lithological units in the study area including migmatites, biotite schist, quartz schist, granite gneiss, calc silicate gneiss and charnockite. Migmatites are the dominant rock type constituting about $70 \%$ of the study area. Migmatites of this area has been described as 'embrechite"' (Odeyemi, 1977), to denote those in which the structural features of original crystalline rocks are wholly or partially preserved. (An anatexite is one in which the crystalline structures are at best faint). The rock is made up of two portions: the paleosome and the metasomes. The paleosome is usually biotite-, biotite-hornblende schist and gneiss (Magongo, Ogori, Ineme Okpe, etc) or amphibolite schist (Ekon). It occurs as concordant bands in the migmatite. In some cases, a well defined layering in the paleosome imparts a characteristic schistosity on the rock.

The metasomes is of quartzo-feldspathic composition and occur in various ways on the field: as concordant to discordant veins of granitic to occasionally pegmatitic composition (Okene, Ikakuma axes). They also occur as augen-shaped crystals of pink microcline feldspar which are aligned to pre-existing foliation in the host rock. Furthermore, they occur as randomly oriented impregnations within the host rock and as parallel to semi parallel bands alternating sequentially with gneisses, (Arima axis).

The contact between the metasomes and gneiss is often irregular, but occasionally sharply defined by a biotite selvedge. The mineralogy of the metasomes is simple, consisting dominantly of quartz and microcline with accessory biotite. The texture is coarse grained, granoblastic, and microcline occasionally forms hypidiomorphic crystals in a quartz-feldspar-biotite mesostasis. Biotite occurs as small inclusions in microcline and quartz. Relationships between the metasomes and the paleosome vary considerably and result in a variety of migmatitic structures. A continuous network of quartzo-feldspathic material cuts large amphibolitic sheets into small irregular blocks producing in the process, agmatitic gneiss.

Gneisses are foliated or banded biotite, and/or hornblende gneiss in which quartzo-feldspathic and/or mafic portion define a bandin. Along Okene-Ogori road, quartzo-feldspathic materials occur as small discrete and 
impersistent streaks invariably aligned to foliation trend of the host rock. The contact between both mafic and felsic bands or streaks within the biotite gneiss is diffuse and gradational. Transition from leucocratic to melanocratic bands is imperceptible, consequent only on a gradual increase in the mafic component. Banding in the gneiss varies in attitude, thickness and persistence. The thickness of individual may vary from fractions of a centimetre to several centimetres, strictly depending on which of the dark and light bands predominates. More commonly, the dark bands are subordinate to the light bands. In places, the bands may be continuous while elsewhere, a single band may split into smaller units with small lenses of mafic/ultramafic materials between them. The dark bands are rich in biotite and amphibole while light layers are found to be of granite composition where banding is minimal or absent (transition gneiss) faint foliation is define by the parallel orientation of the mafic minerals which occur as discrete streak and lensoid aggregates. In cases where banded and biotite gneiss are associated, foliation in the granite gneisses seems to be related to the axial planes of folds in the axial planes of folds in the banded gneisses.

At the northwest, around Ekon-Ikakuma-Arima axis, the migmatites consist of relatively competent mafic layer found within granitic leucosomes. The competent (mafic) bands are boudinaged, with the melt ponding in the boudin neck (figure 6). In other places however, the melt ponds in extensional shear band that is at moderate angle to foliation and parallel leucosomes. At the south of Ikakuma, two systematic sets of leucosomes are deflected at moderate angle by shear bands with diffuse margins. Two sets are texturally continuous, indicating their development was progressive. Along a stream channel which runs northeast-southwest, north of Ekor, there are exposures of network of veins consisting of pure as well as sheared quartz. Also witnessed here are a bit of undeformed charnockitic mafic enclave. Majority of the quartz strike northeast-southwest $\left(021^{0}\right)$ and dip almost vertical at about $87^{0}$ in the northwest direction. Generally, the bands of leucocratic veins vary between 2-4 mm while the metamorphic bands range between $1 \mathrm{~cm}$ and $5 \mathrm{~cm}$ in width. The foliation plane is northeast-southwest $\left(02^{0}-021^{0}\right)$ in orientation.
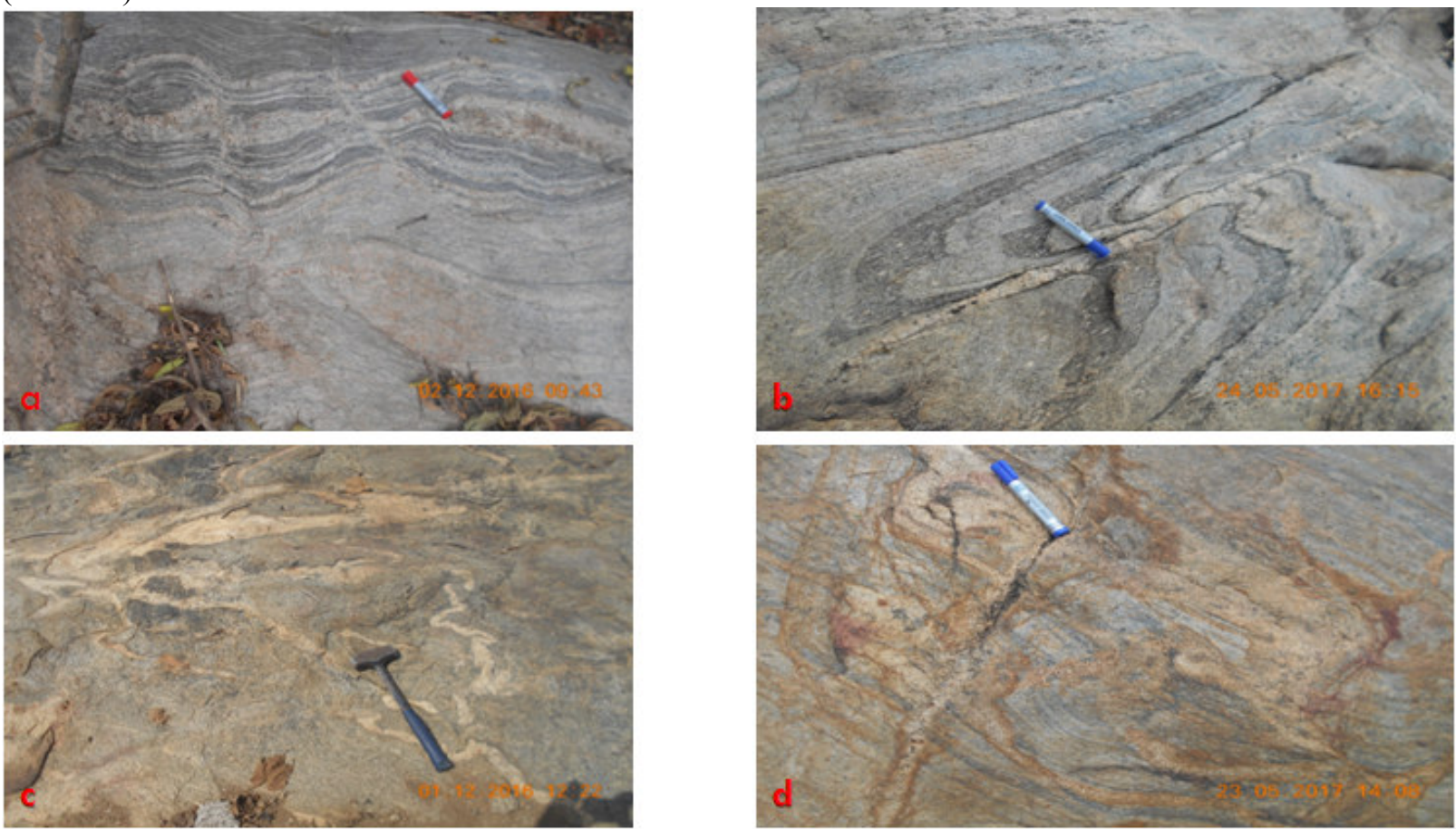

Figure 6: (a) \& (b) boudinaged mafic layer within granitic leucosomes; (c) \& (d) Different orientation and composition of quartzo-feldspathic Metasome

To the southeast of the study area around Ogori-Magongo, rocks are predominantly characterized by parallel gneissosity and leucosomes, with the later forming continuous coarse to medium grained layers. Foliation trend is roughly northwest-southeast $\left(\mathrm{N} 15^{\circ} \mathrm{W}\right)$. In places, the leucosomes are ptigmatically folded with the fold axis parallel to foliation (figure 7). Generally, they have sharp boundary, comprising of minerals such as quartz, feldspar, muscovite with garnet porphyroblast embedded within them. To the southeast of Magongo, towards Ogori, gneisses are relatively fine-grained with weak discontinuous bands of felsic veins made up of quartz, biotite and amphiboles. However, to the north of Magongo, felsic bands become stronger with three generations of veins observable. The first set of veins runs parallel to foliation, (NW-SE; N26 ${ }^{0} \mathrm{~W}$ ) and ranges in size from $7 \mathrm{~mm}-3 \mathrm{~cm}$ in width; the second sets runs NE-SW, $\left(\mathrm{N} 11^{\circ} \mathrm{E}\right)$ in orientation while the third set runs roughly E-W and are the minor set. Xenoliths of more mafic (older), metapellite which are oriented parallel to foliation are also observable. Further northeast of Magongo, veins are composed of quartzitic materials whose major orientations are parallel to 
foliation in a low-lying outcrop. Here also, the composition of Migmatite is that in which the neosome is dominated with $\mathrm{K}$-feldspar, thereby giving the migmatite a generally pink coloration with bands of mafic minerals embedded in them besides the mafic xenoliths. Plane of foliation here vary between NW-SE and NNE-SSW (N36 ${ }^{\circ} \mathrm{W}$ and $\mathrm{N} 06^{0} \mathrm{E}$ respectively). Still further east, quartz veins which runs generally E-W abounds but the trend of foliation is NE-SW (N32 $\left.{ }^{\circ} \mathrm{E}\right)$, while pegmatitic and aplitic dykes shows opposite orientation of NNE-SSW $\left(\mathrm{N} 15^{\circ} \mathrm{E}\right)$ and NWSE respectively.

At Ogori axis, the trend is similar, however, leucocratic neosome dominates the bands; dominant foliation trend is in NE-SW, ranging between $\mathrm{N} 16^{\circ} \mathrm{E}$ to $\mathrm{N} 50^{\circ} \mathrm{E}$, followed by the E-W and then N-S trending ones. The E$\mathrm{W}$ trending veins, though compositionally continuous with the other sets, represent the last phase of a progressive deformational episode. As one moves to the extreme southeast of the study area, the rocks display foliation trend that is weak and dominated by pinkish K-feldspar coloration; this probably is due to the proximity of the Ososo granitic pluton.
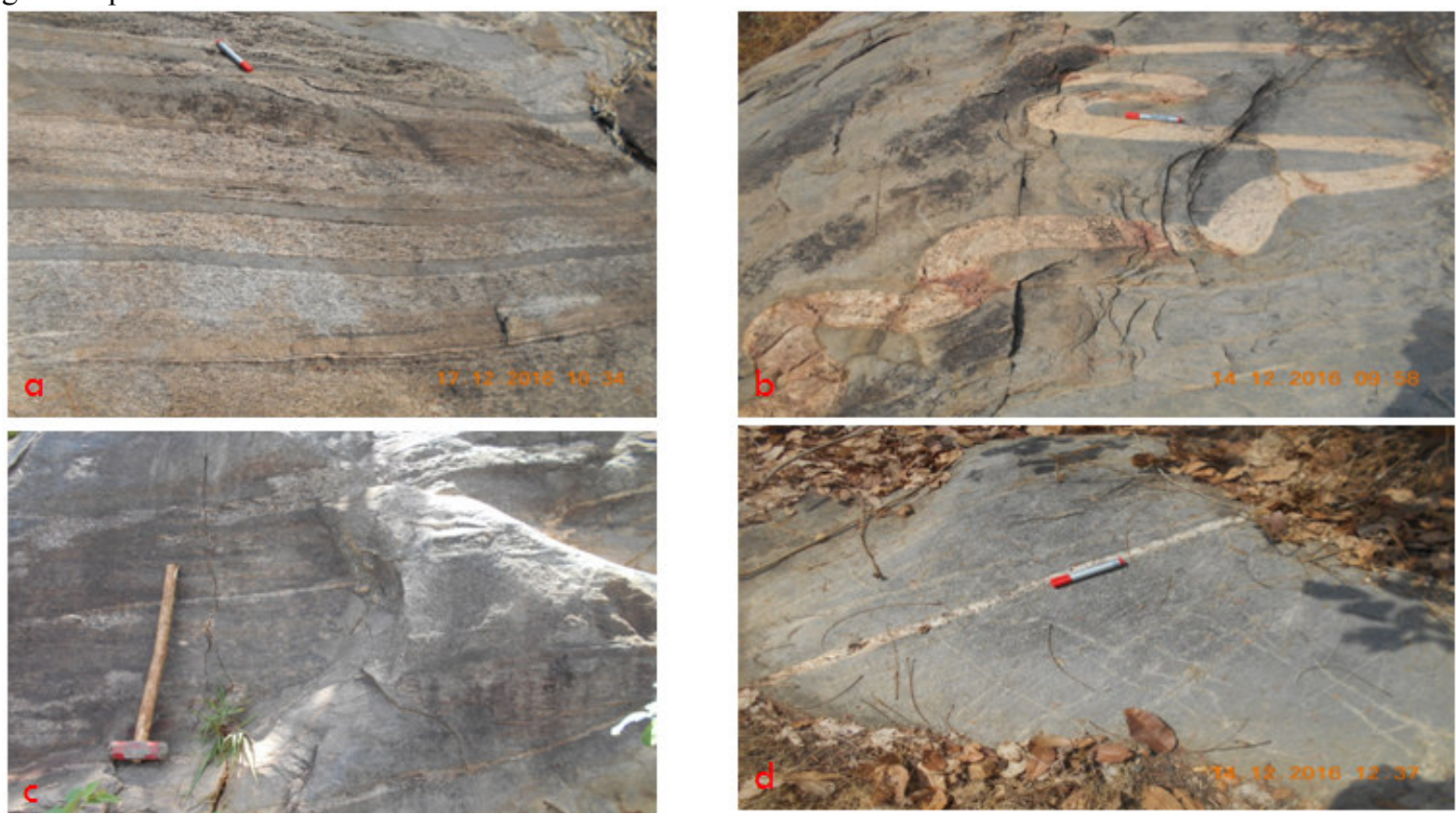

Figure 7: (a) continuous coarse to medium grained parallel gneissic bands in rocks; (b) ptigmatically folded vein; (c) weak foliation trend; (d) Different generations of veins.

At the central part of the study area around Ogale, migmatite show irregular, generally discontinuous leucosomes in migmatised metabasites. Well-developed melanosome selvedges indicate in-situ partial melting and relatively large size of leucosomes and lobate boundaries suggest relatively high melt fraction and coalescence of melt patches. Locally, they have connected to form stroma that would have accommodated melt migration. There are also some discrete stromata with well-developed melanocratic selvedges. Development of parallel leucosomes suggests that there were external stresses. The major foliation trend here is in the NW-SE and N-S direction. Majority of the veins which are quartzitic in nature are parallel to this plane. The composition of the migmatite is predominantly metabasic rock of probably charnockitic or dioritic protolith, particularly to the southwest of this central area. To the northeast of this area however, the leucosomes tend to dominate whereby the melanosomes form patches of xenoliths within them. The leucosomes are granitic in composition with minimal non-penetrating gneissic bands. Patches of melanosomes occur as isolated xenoliths, increasing in sizes in some places as relics. Quartzo-feldspathic veins cut across in different orientation of NE-SW as well as E-W. In between these two extremes, there are areas to the north of Ogale town where the neosome is mesocratic with the more melanocratic paleosome preserved in between bands which are in turn tightly folded in such a way that the fold axis is still parallel to the plane of foliation in the N-S $\left(\mathrm{N} 16^{\circ} \mathrm{W}\right)$ direction.

At the north-eastern part of the study area, just like the northwest, relatively competent mafic layers are boudinaged with melt ponding in boudin neck; melt is represented by coarser grained, lighter-coloured granitic materials and also contain discontinuous screens of mafic rocks that can be seen to be deflected upwards into boudin neck. This relation probably suggests that this is also asymmetric vein cluster that indicates way-up during partial melting. Also in some place within this area, melt ponds to form series of vertical sheets in sheared axial planes of upright folds. Folded layering also contains layer-parallel leucosomes that are locally deflected and truncated by shears as well as texturally continuous with melt in shears in other places which indicates progression from earlier, layer-parallel leucosomes development to folding with flow most likely occurring from latter 
leucosomes into axial plane parallel shears. At still some other places, the melt ponds in extensional shear band that is at moderate angle to foliation and parallel leucosomes. Leucosomes in shear band has very irregular edges and are texturally continuous with layer-parallel leucosomes. This probably suggests that melt is moving along foliation planes and into low pressure tear represented by shear band.

Around Ohuepe, northwest of Okene main town, apart from the darker neosome, there are also xenoliths of yet darker rocks which are oriented parallel to foliation in the NE-SW $\left(\mathrm{N} 30^{\circ} \mathrm{E}\right)$ direction. Here, the orientation of network of quartzo-feldspathic veins is however in the E-W, ranging in width between $1-2 \mathrm{~cm}$ (figure 8). To the east of the town, quartzo-feldspathic veins as well as xenoliths of older, more mafic rocks became more pervasive than in the south, though the foliation plane remain essentially the same. At the far northeast, around Kakun, the outcrops of migmatitic gneisses show greater degree of deformation which vary from place to place. Correspondingly, foliation plane vary between NW-SE $\left(\mathrm{N} 10^{\circ} \mathrm{W}-\mathrm{N} 48^{\circ} \mathrm{W}\right)$ and $\mathrm{E}-\mathrm{W}\left(\mathrm{N} 88^{0} \mathrm{E}\right)$.

At Usungwe community, still northwest of Okene town, foliation is NW-SE, (approximately N610W). Network of veins and dykes vary in composition from quartzo-feldspathic to aplitic and pegmatitic. The aplite and pegmatite are of random orientation but majority of them are perpendicular to the plane of foliation. East of the study area which is in Okene town is of similar structural disposition as observed in Usungwe, however, the network of veins are complexly deformed. Melanosomes vary from discontinuous to thick bands of up to $12 \mathrm{~cm}$. Leucosomes range from $5 \mathrm{~mm}$ to $16 \mathrm{~cm}$ in thickness. Folded bands have axis oriented NW-SE (between N38 ${ }^{\circ} \mathrm{W}$ and $\mathrm{N} 50^{\circ} \mathrm{W}$ ). Local displacement of bands by way of localized faulting is evident. Generally here, a thin layer of mica schist rest unconformably on the outcrop.
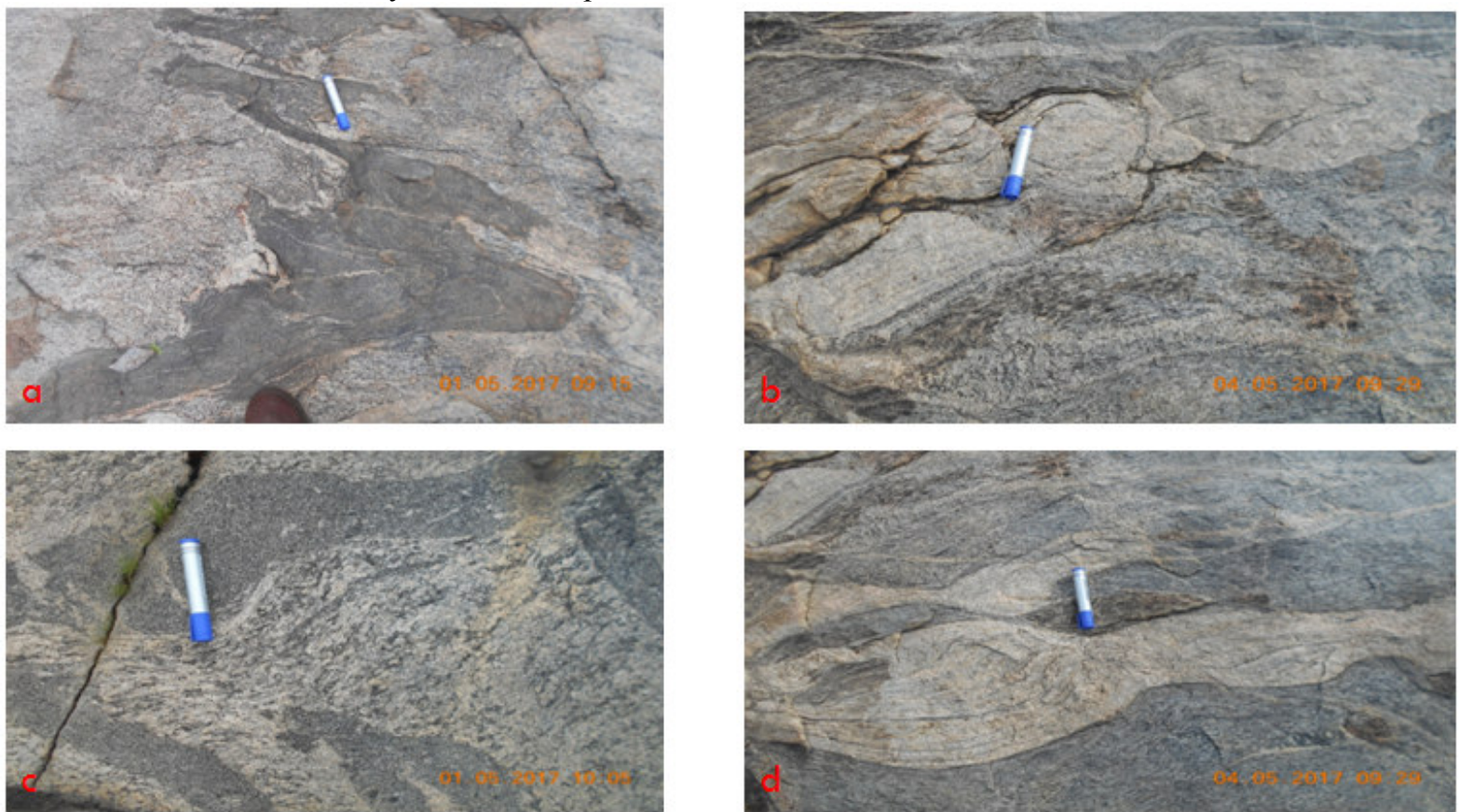

Figure 8: (a) patches of melanosome xenoliths within leucosomes; (b) coarse grained, lighter-coloured granitic leucosomes; (c) \& (d) Irregular, discontinuous leucosomes in migmatite. 


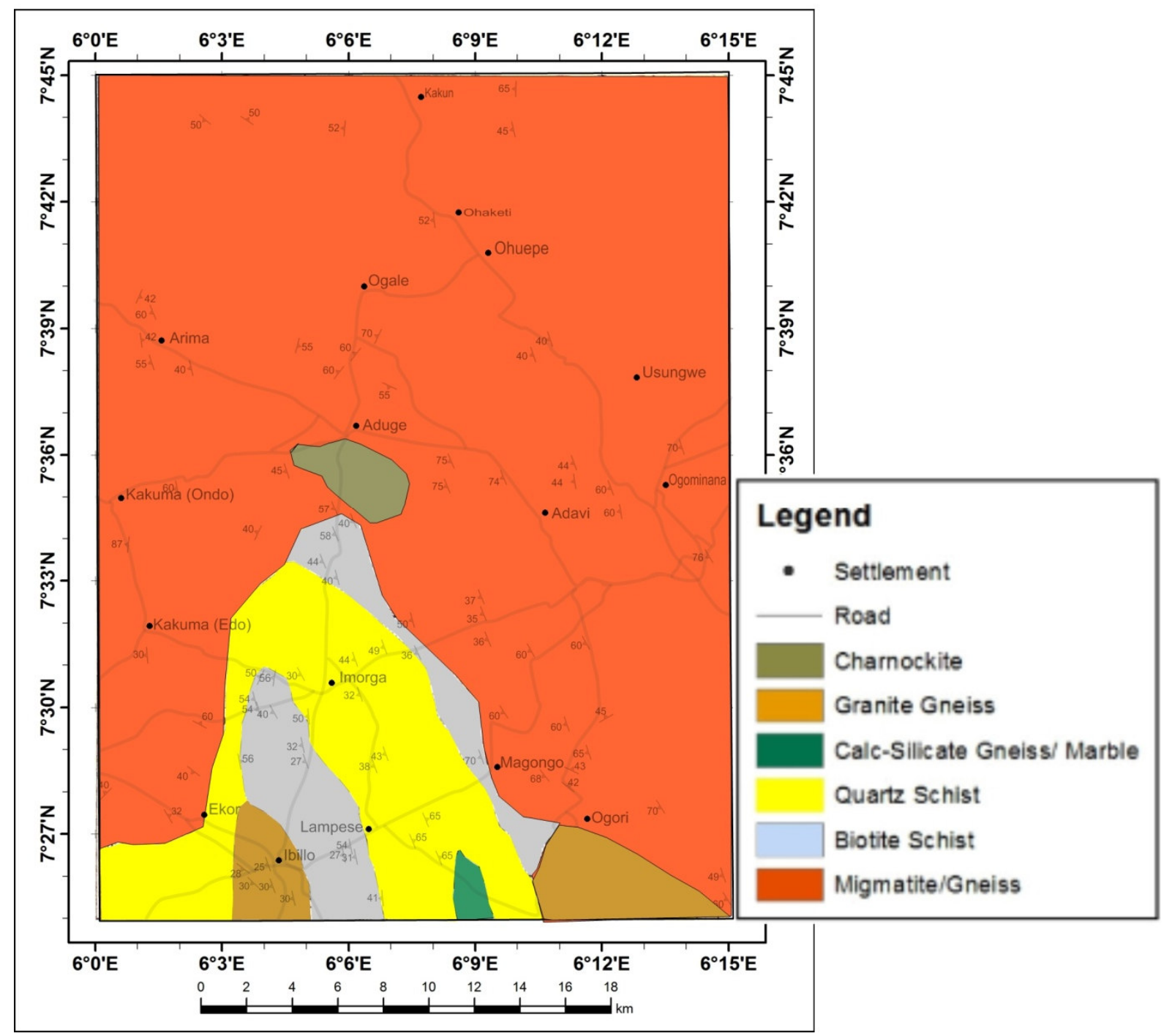

Figure 9: Geological map of the study area

\section{Deformational history}

Based on the DEM analysis, it was established that three major deformation phases (D1, D2 and D3), were identified to have affected the study area. The shaded relief model (Fig. 2c) in addition to field observations, captures these deformational phases.

The first observed D1 deformation involved ductile deformation, which produced isoclinal F1 folds. This fold is axial planar such that both the eastern and western limbs are parallel with the regional metamorphic foliations (S1) and dominant lineaments trends in NNW - SSE and ENE-WSW directions respectively. The dip angle is generally sub-vertical, with value ranging from $60^{\circ}-85^{\circ}$ both in the eastern and western directions. Evidence of these dipping directions is provided by dip-slopes observed on the limbs of the fold on the shaded relief model (Figs. 2c). Both DEM and field observation indicated that the major fold is an antiform structure.

The D2 event is believed to have produced a progressive re-activation of the D1 event with accentuation of the E-W compression leading to folding of the axis of the F1 folds and also the S1 foliation. Evidence of D2 event can be identified as F2 folds which are localized in the right limb of the F1 fold. They are gentle to open folds with inter-limbs angle between $90^{\circ}$ and $110^{\circ}$. Their axial orientations are generally oblique to the regional lineament but axial planar to metamorphic foliations (S2). Evidence from Fig. 2c, suggests that part of the possible displacement mechanism during this regime brought about gliding of the major recumbent fold (F1) along a displaced structural unit. It is believed that it was during this tectonic regime that the initial structural unit became separated or faulted, creating gliding pathway for the fold. Additionally, the D2 event similarly produced a reorientation of the axial surfaces (NNE-SSW) of the F1 folds to the present orientation of the axial surfaces (NESW) of F2 folds whose axial traces are high-obliquely related to the regional structural lineament.

At the scale of the DEM analysis, two deformation stages for the D3 are proposed. The D3 event is believed 
to have produced ductile deformation at the onset at a higher temperature and pressure in the granitic and migmatitic gneisses; and brittle deformation in the quartzites at the later stages with a lower temperature and pressure.

The ductile structures are characterised by series of curvi-planar, sigmoidal foliation with orientation ranging from NE-SW to approximately E-W direction along maximum strain. The development of the sigmoidal foliations is compatible with an intensification of the maximum compressive stress acting in the E-W direction. They are also responsible for the sigmoidal twisting of F1 fold limbs leading to fracturing and displacement of the F1 fold limbs at the later stages of the D3 deformation event. Similar ductile deformation within the basement complex of Nigeria was observed by Anifowose and Kolawole (2012) where granite intrudes the migmatite-gneisses. Intrusion of magma forcefully into the country rock has also been observed to produce ductile deformation including folding and shearing in the country rock near the margins of the pluton (e.g. He et al., 2009). The brittle deformations of this regime are characterised by fractures (Fig. 5c) oriented in the E-W direction in competent rocks, essentially the migmatites. Obviously, the sigmoidal structures associated with the D3 ductile event are characteristics of ductile shear zone. This could probably be addressing one of the questions raised by Ajibade and Wright (1989) on other major fracture (shear zone) systems to be identified except from the ones identified as described by Hubbard (1975) which are generally trending N-S within the Nigerian basement complex.

\section{CONCLUSION}

Lithological mapping and structural analysis play a pivotal role in mineral exploration. Remote sensing approach in lithological discrimination is influenced by difference in reflectivity of different rock types in the visible to shortwave portion of the electromagnetic spectrum. This reflectance is however affected by factors such as weathering and vegetation cover hence the need for ground truthing.

The general trend of the lineaments in study area can be described as NW-SE and NE-SW this trend is consistent with previous reports by Turner (1983) and Odeyemi (1988). Lengths of lineaments also follow this dominant trend. The direction between $\mathrm{N} 45^{\circ}-\mathrm{N} 60^{\circ} \mathrm{E}$ have the highest frequency of lineament which is followed by the direction $\mathrm{N} 65^{\circ}-\mathrm{N} 75^{\circ} \mathrm{E}$ and then $\mathrm{N} 140^{\circ} \mathrm{E}-\mathrm{N} 150^{\circ} \mathrm{E}$. Based on this frequency the trend of the lineaments in the area can be described as NNW-SSE, ENE-WSW and E-W. Foliation planes as observed from field measurements are predominantly NW-SE while joints and fractures are predominantly E-W. Extracted lineament and drainage maps showed a structurally controlled pattern of drainage with channels taking their sources from the peak of the hills.

Geologic fieldwork revealed that the migmatites are essentially metatexites which to the northwest is dialational, dialational net-structured in the northeast and straumatic in the southeast. It is also observed that metamorphic grade and intensity of deformation increases northwards. The southwest of the area constitute the basinal closure of the Igarra area overlain by relics of the metasedimentary units. This research underscore the relevance of remotely sensed data in geological investigation whose results have important implications in terms of regional tectonics and geological mapping as well as in land-use planning and other areas such as hydrogeology or geotechnics.

\section{REFERENCES}

Abdelsalam, M.G., Stern, R.J., (1999): Mineral exploration with satellite remote sensing imagery: examples from Neoproterozoic Arabian shield. J. Afr. Earth Sci. 28, 4a.

Abrams, M.J., Brown, D., Lepley, L., Sadowski, R., (1983): Remote sensing for porphyry copper deposits in southern Arizona. Econ. Geol. 78, 591-604.

Adekoya, J. A. (1999): Rocks and stones: treasure house for national prosperity. Inaugural Lecture Series 19 , Federal University of Technology, Akure.

Ajibade, A.C., Wright, J.B., (1989): The Togo-Benin-Nigeria Shield: evidence of crustal aggregation in the PanAfrican belt. Tectonophysics 165, 125-129.

Anifowose, A.Y.B., Kolawole, F., (2012): Emplacement tectonics of idanre batholith, West Africa. Comun. Geol. $9(2), 13-18$.

Anifowose, A.Y.B., Borode, A.M., (2007): Photogeological study of the fold structure in Okemesi area, southwestern Nigeria. J. Min. Geol. 43 (2), 125-130.

Annor, A. E., Olobaniyi, S. B. and Mucke, A. (1996): A note on the geology of Isanlu area in the Egbe-Isanlu Schist Belt, SW Nigeria. Jour. Min. Geol. vol 32, no. 1, pp 47-51.

Ayodele, O.S., Odeyemi, I.B., (2010): Analysis of lineaments extracted from Landsat TM imagery of Okemesi area, southwestern Nigeria. Indian J. Sci. Technol. 1, 34-38.

Caby, R., (1989): Precambrian terranes of Benin-Nigeria and northeast Brazil and the late proterozoic south atlantic fit. Geol. Soc. Am. Special Pap. 230, 145-158.

Dada, S.S., (2006): Proterozoic evolution of Nigeria. In A Tribute to Prof. M. A. O. Rahaman Oshin, O. (Ed.), The Basement Complex of Nigeria and its Mineral Resources. Akin Jinad and Co, Ibadan, pp. 29-44. 
Dada, S.S., Dupre, B., Brique, L., Rahaman, M., (1994): Geochemical characteristics of reworked archean gneiss complex of North-Central Nigeria. Abstr.-30th Annu. Conf. Niger. Min. Geosci. Soc. 65.

Drury, S.A., (1987): Image Interpretation in Geology, first ed. Allen and Unwin, London.

Drury, S.A., (2001): Image Interpretation in Geology, third ed. Nelson Thornes, Cheltenham,UK.

Elueze, A.A., (1988): Geology of the Precambrian schist belt in llesha area, southwestern Nigeria. In: Oluyide, P.O., et al. (Eds.), Precambrian Geology of Nigeria. pp. 77-89 (Geological Survey of Nigeria).

Exelis VIS, (2000): Some details on ENVI's Principal Components algorithm. Retrieved from http://www.exelisvis.com/Company/PressRoom/TabId/190/ArtMID/786/ArticleID/2765/2765.aspx

Gad, S., Kusky, T., (2002): Lithological mapping in the Eastern Desert of Egypt, the Barramiya area, using Landsat thematic mapper (TM). J. Afr. Earth Sci. 44, 196-202.

He, B., Xu, Y.G., Paterson, S., (2009): Magmatic diapirism of the Fangshan pluton, southwest of Beijing, China. J. Struct. Geol. 31, 615-626.

Hung, L.Q., Batelaan, O., De Smedt, F., (2005): Lineament extraction and analysis, comparison of Landsat ETM and ASTER imagery: case study - suoimuoi tropical karst catchment, Vietnam. In: In: Ehlers, Manfred, Michel, Ulrich (Eds.), Remote Sensing for Environmental Monitoring, Volume V: GIS Applications and Geology. vol. 5983, p. 12. Proceedings of SPIE.

Karnieli, A., Meisels, A., Fisher, L., Arkin, Y., (1996) Automatic Extraction and Evaluation of Geological Linear Features from Digital Remote Sensing Data Using a Hough Transform.

Kaufmann, H., (1988): Mineral exploration along the Aqaba-levent structure by use of Landsat TM data; concepts, processing, and results. Int. J. Remote Sens. 9, 1639-1658.

Kiran, R.S., Ahmed, S.A., (2014): Lineament extraction from southern chitradurga schist belt using Landsat TM, ASTERGDEM and Geomatics techniques (0975-8887).Int. J. Comput. Appl. 93 (12).

Odeyemi, I.B., (1993): A comparative study of remote sensing images of structure of the Okemesi fold belt, Nigeria. ITC Neth. J. 1, 77-81.

Odeyemi, I. B. (1988): Lithostratigraphy and structural relationships of the Upper Precambrian Metasediments in Igarra area, southwestern Nigeria. In: Oluyide, P. O., W. C. Mbonu, A. E. Ogezi, I. G. Egbuniwe, A. C. Ajibade, and A. C. Umeji. (editors), Precambrian geology of Nigeria. Publ. GSN. pp $111-125$.

Odeyemi, I., (1981): A review of the erogenic events in the Precambrian basement of Nigeria, West Africa. Geol. Rundsch. 70, 897-909.

Olobaniyi, S. B. and Annor, A. E. (1997): The occurrence of Komatiitic Ultramafic schist in the Egbe-Isanlu schist belt, SW Nigeria and its age implications. Abstract. Nig. Min. and Geo. Soc. $33^{\text {rd }}$ Annual Conference, Jos 97, p 12-13.

Pawley, M., Reid, A. Dutch, R. \& Preiss, W. (2015): Demystifying migmatites: introduction for field-based geologist, Applied Earth Science, 124:3, 147-174, DOI: 10.1179/1743275815Y.0000000014

Rahaman, M.A., (1988): Recent Advances in the Study of the Basement Complex of Nigeria Precambrian Geology of Nigeria. 11-43.

Turner, D.C. (1983): Upper Proterozoic Belts in the Nigerian Sector of the Pan-African Province of West Africa. Precambrian Research (Elsevier Science Publishers), 21, pp. 55-79.

Wright, J.B., Hastings, D.A., Jones, W.B. and Williams, H.R. (1985): Geology and Mineral Resources of West Africa. George Allen (Boston) \& Unwin (Sydney), London. 